\title{
Optimization and Evaluation of Heat-shock Condition for Spore Enumeration Being Used in Thermal-process Verification: Differential Responses of Spores and Vegetative Cells of Clostridium sporogenes to Heat Shock
}

\author{
Bo Young Byun, Yanhong Liu, Juming Tang, Dong-Hyun Kang, Hong-Yon Cho, Han-Joon Hwang, and \\ Jae-Hyung Mah
}

Received: 7 January 2011 / Revised: 7 February 2011 / Accepted: 23 February 2011 / Published Online: 30 June 2011

(C) KoSFoST and Springer 2011

\begin{abstract}
To evaluate a heat-shock condition for the enumeration of Clostridium sporogenes spores, a surrogate for $C$. botulinum spores, we examined the heat tolerance of C. sporogenes spores and vegetative cells exposed to a heat shock at $90^{\circ} \mathrm{C}$. From the $\mathrm{D}$ values of the spores determined in the temperature range of $113-121^{\circ} \mathrm{C}, z$ value $( \pm \mathrm{SD})$ and $\mathrm{D}_{90^{\circ} \mathrm{C}}$ value were estimated to be $10.16 \pm 0.90^{\circ} \mathrm{C}$ and $1,071.52 \mathrm{~min}$, respectively, and the inactivation rates were predicted to be only approximately $2 \%$ at $90^{\circ} \mathrm{C}$ for up to 10 min. Meanwhile, the viable count of spores was significantly higher when activated under a heat-shock condition of $90^{\circ} \mathrm{C}$ for over $9 \mathrm{~min}$ than those activated for shorter time periods. The heat tolerance of vegetative cells was extremely low, showing a $\mathrm{D}_{90^{\circ} \mathrm{C}}$ value $( \pm \mathrm{SD})$ of $0.21 \pm 0.01 \mathrm{~min}$. Finally, 3 different heat-shock conditions were compared: $70^{\circ} \mathrm{C}$ for $30 \mathrm{~min}, 80^{\circ} \mathrm{C}$ for $20 \mathrm{~min}$, and $90^{\circ} \mathrm{C}$ for $10 \mathrm{~min}$, and the experimental comparative data showed no significant differences in viable spore counts. Consequently, these
\end{abstract}

Bo Young Byun, Hong-Yon Cho, Han-Joon Hwang, Jae-Hyung Mah ( $\varangle)$ Department of Food and Biotechnology, Korea University, Jochiwon, Chungnam 339-700, Korea

Tel: +82-41-860-1431; Fax: +82-41-865-0220

E-mail: nextbio@korea.ac.kr

Yanhong Liu

College of Engineering, China Agricultural University, Beijing 100083, China

Juming Tang

Department of Biological Systems Engineering, Washington State University, Pullman, WA 99164-6120, USA

Dong-Hyun Kang

Department of Agricultural Biotechnology, Seoul National University, Seoul 151-921, Korea results support that the heat-shock treatment at $90^{\circ} \mathrm{C}$ for 10 $\mathrm{min}$ is suitable to activate spores and to inactivate vegetative cells of $C$. sporogenes.

Keywords: Clostridium sporogenes, spore, vegetative cell, enumeration, heat shock

\section{Introduction}

Clostridium sporogenes PA 3679 is a non-pathogenic, putrefactive, spore-forming anaerobe, and its spores have been successfully used as an excellent surrogate for modeling thermal inactivation processes of Clostridium botulinum type A and B spores (1-4). Furthermore, $C$. sporogenes has a distinguished value as the only possible surrogate for proteolytic strains of $C$. botulinum, belonging to the genus (5).

In both modeling and validating thermal sterilization processes for inactivating C. botulinum spores, it is essential to obtain accurate information on inoculum size and spore survival of $C$. sporogenes and hence to provide reliable data on the heat resistance and thermal inactivation of $C$. sporogenes spores. In general, the viable spores of $C$. sporogenes are counted after subjecting samples to a heatshock (or heat-activation) treatment, i.e., a condition of $90^{\circ} \mathrm{C}$ for $10 \mathrm{~min}$ used in other studies validating thermal sterilization processes $(6,7)$, and conventional conditions of $70^{\circ} \mathrm{C}$ for $30 \mathrm{~min}(8,9)$ and of $80^{\circ} \mathrm{C}$ for $20 \mathrm{~min}(10-12)$; the spores are used in the unheated controls in these studies and not the samples that are heated. Any of the cited combinations are believed to be sufficient to activate 
spores and to inactivate vegetative cells of any strains tested. Considering the importance of activating spores and maximizing germination rates (13), however, clear scientific evidence is required to support the belief that a heat-shock treatment may be suitable to activate spores.

Recently, there has been a revival of interest in validating and improving the procedure for enumeration of Bacillus spores by using different heat-shock treatments (14). On the other hand, less work has been done on $C$. sporogenes spores which are of importance in validating thermal inactivation of $C$. botulinum spores. Furthermore, to our knowledge, surprisingly, no study has been reported providing scientific evidence that a heat-shock condition of $90^{\circ} \mathrm{C}$ for $10 \mathrm{~min}$ commonly used by industry people in the United States is appropriate to activate $C$. sporogenes spores. In this study, therefore, we first examined the degree of tolerance of $C$. sporogenes spores and vegetative cells to a heat shock at $90^{\circ} \mathrm{C}$, and observed the behavior of both spores and vegetative cells during the heat-shock treatment. Next, we evaluated a heat shock at $90^{\circ} \mathrm{C}$ for 10 min used to activate $C$. sporogenes spores in different food samples in our previous study and compared the results with those obtained under 2 different conventional heatshock conditions which have been the most widely used for activating the spores in literature. To the best of our knowledge, this is the first study describing the behavior of both spores and vegetative cells of $C$. sporogenes during heat-shock treatment.

\section{Materials and Methods}

Microorganism Clostridium sporogenes PA 3679 (ATCC 7955; American Type Culture Collection, Rockville, MD, USA) spores were obtained from the Center for Technical Assistance of the former National Food Processors Association (NFPA, Dublin, CA, USA). The spore suspension was divided into cryogenic sterile vials (Fisher Scientific, Pittsburgh, PA, USA) and kept at $-20^{\circ} \mathrm{C}$ until use. The initial concentration of the stock suspension was approximately $10^{6} \mathrm{CFU} / \mathrm{mL}$, which was determined by the enumeration procedure described below.

Preparation of vegetative cells To prepare a pure culture of vegetative cells in stationary phase, a multiple stage inoculation procedure was employed with minor modifications (15). The procedure utilized TPGY medium consisted of $50 \mathrm{~g}$ of tryptone, $20 \mathrm{~g}$ of yeast extract, $5 \mathrm{~g}$ of peptone, $4 \mathrm{~g}$ of dextrose, and $1 \mathrm{~g}$ of sodium thioglycolate (Difco, Becton Dickinson, Sparks, MD, USA) in $1 \mathrm{~L}$ of distilled water (16). Ten $\mathrm{mL}$ of TPGY broth were inoculated with $10 \mu \mathrm{L}$ stock spore suspension and incubated for 2 days at $32^{\circ} \mathrm{C}$ in an anaerobic chamber (Coy Laboratory
Products Inc., Grass Lake, MI, USA) containing an atmosphere of 95\% nitrogen and 5\% hydrogen (Oxarc Inc., Spokane, WA, USA). Subsequently, $10 \mathrm{~mL}$ of TPGY broth was inoculated with $0.1 \mathrm{~mL}$ of the previous culture, which was followed by incubation under the same conditions. To obtain a purified suspension of vegetative cells, the culture was washed 3 times by centrifugation in an Eppendorf 5415C microcentrifuge (Brinkmann Instruments Inc., Westbury, $\mathrm{NY}$, USA) at $14,000 \times \mathrm{g}$ for $10 \mathrm{~min}$ at $4^{\circ} \mathrm{C}$, resuspended in $10 \mathrm{~mL}$ of M/15 Sörensen's phosphate buffer $\left(\mathrm{Na}_{2} \mathrm{HPO}_{4}\right.$ $5.675 \mathrm{~g}, \mathrm{KH}_{2} \mathrm{PO}_{4} 3.63 \mathrm{~g}$ in $1 \mathrm{~L}$ of distilled water, $\mathrm{pH}$ 7.0). The purified vegetative cell suspension was immediately subjected to heat treatment as described below. The concentration of the vegetative cell suspension was approximately $10^{6} \mathrm{CFU} / \mathrm{mL}$, which was determined by the enumeration procedure described below.

Enumeration of spores and vegetative cells The spore suspension sample was placed in a $90^{\circ} \mathrm{C}$ water bath for 10 min to stimulate germination of the spores and to kill vegetative cells. After heat treatment, the suspension was cooled in a crushed ice water bath and serially diluted in sterile $0.1 \%$ peptone water. One $\mathrm{mL}$ of each serially diluted sample was pour-plated using molten $\left(45^{\circ} \mathrm{C}\right)$ TPGY agar. Solidified plates were incubated for 3 days at $32^{\circ} \mathrm{C}$ in an anaerobic chamber. The colonies were manually counted after $72 \mathrm{~h}$ of incubation and the numbers of spores were calculated from duplicate plating.

Enumeration of vegetative cells was made essentially by the same procedure, except for the heating step.

Determination of heat resistance of spores The D values (time required for a 10 -fold reduction in viable counts) of $C$. sporogenes spores were determined using the multiple-point method (17). Test spore suspension was injected into a glass capillary tube with an inner diameter of $1.8 \mathrm{~mm}$ and an outer diameter of $3 \mathrm{~mm}$ (Corning Inc., Corning, NY, USA) using a pipette and then the open ends of the tubes were heat sealed. The tubes were immersed completely in an oil bath (Thermo Electron Corporation, Waltham, MA, USA) and heated between 113 and $121^{\circ} \mathrm{C}$ for different time intervals depending on temperature used. After heating, the tubes were removed from the oil bath, cooled immediately in a crushed ice water bath, and washed in $70 \%$ ethyl alcohol. Both ends of tubes were cut aseptically and the contents flushed out with $3 \mathrm{~mL}$ of sterile $0.1 \%$ peptone water. To enumerate spore survival, the treated suspension was serially diluted in sterile $0.1 \%$ peptone water. One $\mathrm{mL}$ of each serially diluted sample was pour-plated using TPGY agar, incubated in an anaerobic chamber, and then the colonies were manually counted, as described previously.

Survivor curves were plotted on a semi-log chart (log 
survival counts vs. time) to determine $\mathrm{D}$ values. $\mathrm{D}$ values were obtained by taking the reciprocal of the slope from linear regression of the survivor curves. The $z$ value (the change in temperature required for a 10-fold change in the $\mathrm{D}$ value) of $C$. sporogenes spores was estimated by plotting the $\log _{10} \mathrm{D}$ values versus heating temperatures and taking the reciprocal of the slope from linear regression.

Calculation of $D$ values and inactivation rates of spores at lower temperatures The $\mathrm{D}$ values at lower temperatures were predicted using a specific Eq. 1 that was obtained from a slope of the linear regression of $\log \mathrm{D}$ value versus temperature.

$$
D=10^{(-0.0988 \times T+11.922)}
$$

where, $T$ is temperature $\left({ }^{\circ} \mathrm{C}\right)$ and $D$ is the estimated $\mathrm{D}$ value $(\mathrm{min})$ at the temperature. To confirm Eq. 1, the predicted $\mathrm{D}$ values were compared with the $\mathrm{D}$ values calculated by the following generalized Eq. 2 that was suggested by Bolton et al. (18) and Byrne et al. (19).

$$
D_{x}=\log ^{-1}\left[\log D_{y}-\left\{\left(T_{x}-T_{y}\right) / Z\right\}\right]
$$

where, $D_{x}$ is the $\mathrm{D}$ value $(\mathrm{min})$ at a temperature $T_{x}\left({ }^{\circ} \mathrm{C}\right), T_{y}$ is the reference temperature $\left({ }^{\circ} \mathrm{C}\right.$; for example, $\left.121^{\circ} \mathrm{C}\right), D_{y}$ is the $\mathrm{D}$ value $(\mathrm{min})$ at $T_{y}$ and $Z$ is $z$ value $\left({ }^{\circ} \mathrm{C}\right)$. Their equation can be rewritten as $\log D_{x}=\log D_{y}-\left(T_{x}-T_{y}\right) / Z$.

The inactivation rates of the spores at different temperatures from 70 to $100^{\circ} \mathrm{C}$ were estimated using an Eq. 3.

$$
R=100 \times \frac{N}{N_{0}}=100 \times\left(1-10^{-t / D}\right)
$$

where, $R$ is inactivation rate (\%), $N_{0}$ is the initial number of spores, $N$ is the number of inactivated spores, $t$ is heat treatment time (min), and $D$ is $\mathrm{D}$ value $(\mathrm{min})$ at a temperature used.

\section{Heat activation of spores and measurement of $D$ value} of vegetative cells To investigate the responses of spores and vegetative cells of $C$. sporogenes to heat-shock treatments, we used a test tube method (17). A test suspension containing either spores (diluted, $10^{3} \mathrm{CFU} / \mathrm{mL}$ ) or vegetative cells $\left(10^{6} \mathrm{CFU} / \mathrm{mL}\right)$ was dispensed into a preheated 13-mm glass test tube (VWR International, West Chester, PA, USA) containing sterile $0.1 \%$ peptone water. The tubes sealed tightly with lids were immersed in a water bath at $90^{\circ} \mathrm{C}$ and heated for different time intervals given in Fig. 1 and 2. After heating, the tubes were removed from the water bath, cooled immediately in a crushed ice water bath. The heat-treated suspension was serially diluted in sterile $0.1 \%$ peptone water. One $\mathrm{mL}$ of each serially diluted sample was pour-plated using TPGY agar, incubated in an anaerobic chamber, and then the colonies were manually

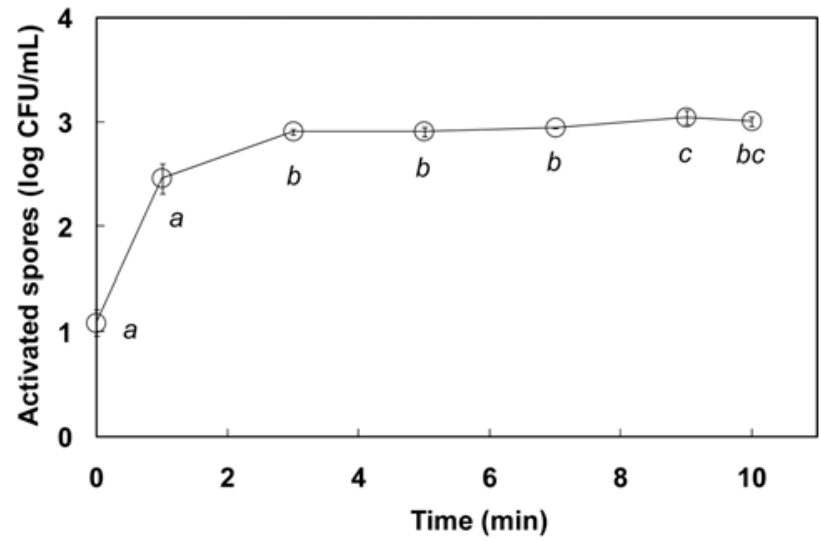

Fig. 1. Thermal activation curve for $C$. sporogenes spores. Error bars indicate standard deviations calculated from 2 independent experiments in duplicate; Means with different letters are significantly different at $p<0.05$ of Fisher's pairwise comparison tests.

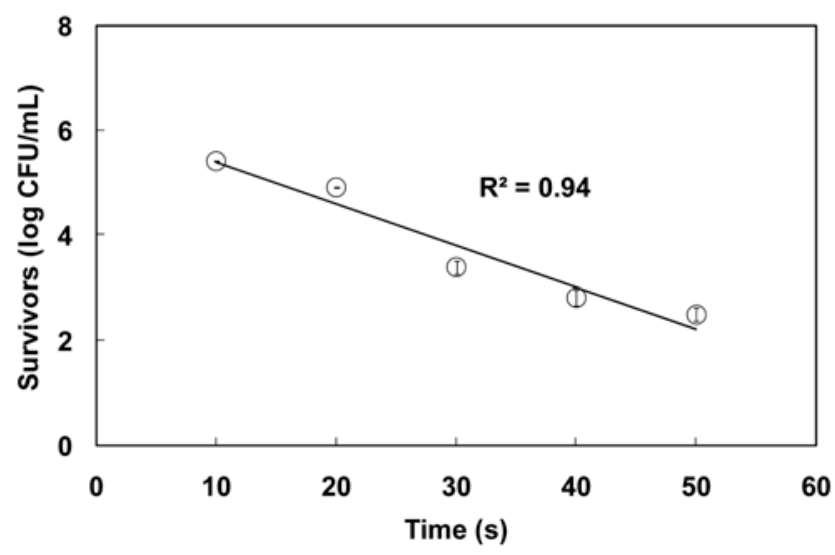

Fig. 2. Thermal survivor curve for $C$. sporogenes vegetative cells. Error bars indicate standard deviations calculated from 2 independent experiments in duplicate.

counted, as described previously. The $\mathrm{D}$ value of vegetative cells was obtained by the same method as for spores.

Activation of $C$. sporogenes spores under different heatshock conditions The diluted spore suspension sample (approximately $10^{3} \mathrm{CFU} / \mathrm{mL}$ of spores) was placed in a $90^{\circ} \mathrm{C}$ water bath for $10 \mathrm{~min}$ (alternatively $70^{\circ} \mathrm{C}$ for $30 \mathrm{~min}$ and $80^{\circ} \mathrm{C}$ for $20 \mathrm{~min}$; Table 3 ) to stimulate germination of the spores. The heat-treated suspension was treated as described above for enumerating spores. The colonies were manually counted after $72 \mathrm{~h}$ of incubation and the numbers of spores were calculated from duplicate plating. Data obtained from 2 independent experiments were compared to evaluate different heat-shock conditions.

Statistical analysis Data were obtained from 2 independent experiments performed in duplicate and presented as mean \pm standard deviation (SD). The significance of differences 
was determined by one-way analysis of variance (ANOVA) with Tukey's and Fisher's pairwise comparison module of the Minitab statistical software, version 12.11 (Minitab Inc., State College, PA, USA) and differences with $p<0.05$ were considered statistically significant.

\section{Results and Discussion}

Heat resistance of $\boldsymbol{C}$. sporogenes spores To obtain information on the degree of tolerance of $C$. sporogenes spores to heating at different temperatures, we first examined the $\mathrm{D}$ and $z$ values of the spores. As shown in Table 1 , the $\mathrm{D}$ values $( \pm \mathrm{SD})$ of $C$. sporogenes spores heated at different temperatures of $113,115,118$, and $121^{\circ} \mathrm{C}$ were determined to be $5.29 \pm 0.12,4.12 \pm 0.07$, $1.81 \pm 0.35$, and $0.92 \pm 0.13 \mathrm{~min}$, respectively. From these experimental $\mathrm{D}$ values, the $z$ value $( \pm \mathrm{SD}$ ) of the spores was estimated to be $10.16 \pm 0.90^{\circ} \mathrm{C}$. Meanwhile, the spores were expected to have a satisfactory tolerance to heating at $90^{\circ} \mathrm{C}$, because a higher $\mathrm{D}_{90^{\circ} \mathrm{C}}$ value of $1,071.52 \mathrm{~min}$ was predicted using a specific Eq. 1 . The predicted $\mathrm{D}$ values at lower temperatures ranging from 60 to $100^{\circ} \mathrm{C}$ are presented on Table 2, which are in agreement with the $\mathrm{D}$ values calculated by Eq. 2. The predicted $\mathrm{D}$ value at $100^{\circ} \mathrm{C}$ is consistent with the experimental $\mathrm{D}_{100^{\circ} \mathrm{C}}$ value (about 110 min in nutrient broth) published previously (20), while there are no available experimental D values at lower temperatures of $70-90^{\circ} \mathrm{C}$ in literature.

To support this observation that $C$. sporogenes spores have a strong tolerance to heating at $90^{\circ} \mathrm{C}$, we estimated the

Table 1. Experimental $D$ and $z$ values of $C$. sporogenes spores

\begin{tabular}{|c|c|c|c|c|}
\hline & & Mean & Variance & $\begin{array}{c}\text { Correlation } \\
\text { coefficient }\left(\mathrm{R}^{2}\right)\end{array}$ \\
\hline \multirow{4}{*}{$\begin{array}{l}\text { D value } \\
\text { (min) at: }\end{array}$} & $113^{\circ} \mathrm{C}$ & $5.29^{1)}$ & 0.12 & 0.95 \\
\hline & $115^{\circ} \mathrm{C}$ & 4.12 & 0.07 & 0.97 \\
\hline & $118^{\circ} \mathrm{C}$ & 1.81 & 0.35 & 0.98 \\
\hline & $121^{\circ} \mathrm{C}$ & 0.92 & 0.13 & 0.99 \\
\hline \multicolumn{2}{|c|}{$z$ value $\left({ }^{\circ} \mathrm{C}\right)$} & 10.16 & 0.90 & 0.99 \\
\hline
\end{tabular}

${ }^{1)}$ Values were calculated from 2 independent experiments performed in duplicate. inactivation rates of the spores at different temperatures, using Eq. 3. The estimated inactivation rates are presented in Table 2. As expected, the inactivation rate of the spores was approximately $2 \%$ under heat-shock conditions of $90^{\circ} \mathrm{C}$ for $10 \mathrm{~min}$. Longer exposures to this temperature beyond $10 \mathrm{~min}$ (up to $30 \mathrm{~min}$ ) were estimated to lead to somewhat increased inactivation rates (approximately 4$6 \%$ ). This, together with the fact that $C$. sporogenes spores have an extremely high $\mathrm{D}_{90^{\circ} \mathrm{C}}$ value of over 1,000 min than the values at higher temperatures, implies that the spores protect themselves well against a heat shock of up to 10 $\min$ at $90^{\circ} \mathrm{C}$.

Behavior of spores and vegetative cells of $C$. sporogenes under heat-shock condition It was attempted to observe the behavior of spores and vegetative cells during the time period of heat-shock exposure at $90^{\circ} \mathrm{C}$. As shown in Fig. 1, the viable counts of $C$. sporogenes spores significantly increased for the first $3 \mathrm{~min}(p<0.05)$ and remained constant for the next $4 \mathrm{~min}(p>0.05)$. Since the spores activated for over $9 \mathrm{~min}$ showed slightly, but significantly $(p<0.05)$, higher viable counts as compared to when they were exposed to the heat shock for shorter time periods, it seemed likely that the heating for 9-10 min was optimal to activate spores at $90^{\circ} \mathrm{C}$. To support this, we compared this condition with conventional heat-shock conditions. The results are shown below.

Meanwhile, heat-shock conditions for the enumeration of spores should be sufficient to inactivate vegetative cells of any strains of spore-forming bacteria, like Bacillus and Clostridium (16,21); otherwise it may cause major errors in the accuracy of spore counts. To test if $C$. sporogenes vegetative cells can survive under a heat-shock condition of $90^{\circ} \mathrm{C}$ for $10 \mathrm{~min}$, therefore, we exposed vegetative cells $\left(2 \times 10^{5} \mathrm{CFU} / \mathrm{mL}\right)$ to the heat-shock condition and observed that more than $99.5 \%$ of the cells lost their viability (data not shown). To further support this observation, we determined the $\mathrm{D}$ value $( \pm \mathrm{SD})$ of the vegetative cells heated at $90^{\circ} \mathrm{C}$. As shown in Fig. 2, a log-linear survivor curve for the vegetative cells was obtained at this temperature where inactivation occurred. From the slope of this curve, the $\mathrm{D}_{90^{\circ} \mathrm{C}}$ value $( \pm \mathrm{SD})$ of $C$. sporogenes

Table 2. Predicted D values and inactivation rates of $C$. sporogenes spores at potential heat-shock temperatures

\begin{tabular}{crrrrrr}
\hline \multirow{2}{*}{ Temperature $\left({ }^{\circ} \mathrm{C}\right)$} & D value $(\min )^{1)}$ & \multicolumn{5}{c}{ Inactivation rate of spores $(\%)$ after heat treatment $(\mathrm{min})^{2)}$} \\
\cline { 3 - 6 } & & 1 & 5 & 10 & 20 & 30 \\
\hline 100 & 110.15 & 2.07 & 9.92 & 18.86 & 34.17 & 46.59 \\
90 & $1,071.52$ & 0.21 & 1.07 & 2.13 & 4.21 & 6.24 \\
$80^{3)}$ & $10,423.17$ & 0.02 & 0.11 & 0.22 & 0.44 & 0.66 \\
$70^{3)}$ & $101,391.14$ & 0.00 & 0.01 & 0.02 & 0.05 & 0.07 \\
\hline
\end{tabular}

${ }^{10} \mathrm{D}$ value was predicted using an Eq. 1 obtained from a slope of the linear regression of log $\mathrm{D}$ value vs. temperature.

${ }^{2)}$ Inactivation rate was estimated using an Eq. 3.

${ }^{3)}$ Conventional heat-shock temperature 
vegetative cells was calculated to be $0.21 \pm 0.01 \mathrm{~min}$, implying that the heat tolerance of the vegetative cells is extremely low as compared with that of spores, as expected. Taken together, it can be concluded that the heatshock condition of $90^{\circ} \mathrm{C}$ for $10 \mathrm{~min}$ is effective in inactivating $C$. sporogenes vegetative cells.

Activation of $C$. sporogenes spores has been conducted under several different heat-shock conditions $(8-12,22)$. However, little information is available regarding inactivation of vegetative cells under heat-shock conditions. To date, several studies on the heat resistance of vegetative cells have been carried out with $C$. perfringens $(19,23,24)$. On the other hand, little study has been found in literature on the heat resistance of $C$. sporogenes vegetative cells. In this study, it turned out that while the number of activated spores of $C$. sporogenes gradually increases until the viable spore count reaches a maximum, the number of vegetative cells decreases logarithmically, as a function of exposure time at $90^{\circ} \mathrm{C}$. This is in agreement with the observation that C. sporogenes spores $\left(\mathrm{D}_{90^{\circ} \mathrm{C}}\right.$ value of $\left.1,071.52 \mathrm{~min}\right)$ had a much greater tolerance at this temperature than vegetative cells $\left(\mathrm{D}_{90^{\circ} \mathrm{C}}\right.$ value of $\left.0.21 \mathrm{~min}\right)$, even though considering a possible tailing and shouldering of the thermal death time curve at a low temperature. Therefore, it can be suggested that, under a heat-shock condition of $90^{\circ} \mathrm{C}$ for $10 \mathrm{~min}$ for activating $C$. sporogenes spores, the probability of vegetative cell survival is negligible.

Meanwhile, when we exposed vegetative cells (about $3 \times$ $10^{3} \mathrm{CFU} / \mathrm{mL}$ ) to heat at $121^{\circ} \mathrm{C}$, no vegetative cell survivors were detected after $5 \mathrm{~s}$ in our preliminary study (data not shown). This implies that the $\mathrm{D}$ value of $C$. sporogenes vegetative cells at $121^{\circ} \mathrm{C}$ is much less than $5 \mathrm{~s}$, which in turn is smaller than the variance of $\mathrm{D}$ values of $C$. sporogenes spores determined at $121^{\circ} \mathrm{C}$ (Table 1). Furthermore, the come-up time (the time to reach the desired temperature) of capillary tubes that contain spore suspension to be tested for heat resistance is approximately $3 \mathrm{~s}$ at this temperature $(25,26)$. This body of information therefore indicates that the presence of vegetative cells in a given suspension and/ or food sample does not affect the enumeration of spore survivors after exposure to $121^{\circ} \mathrm{C}$.

\section{Comparison of viable spore counts of $C$. sporogenes spores activated under different heat-shock conditions} If heat-shock treatment is too severe, the damage will be so strong that the spores cannot repair themselves and the viable spore counts will be smaller, compared with conventional and mild heat-shock conditions. Therefore, we compared a heat shock at $90^{\circ} \mathrm{C}$ for $10 \mathrm{~min}$ with 2 different conventional heat-shock conditions of $70^{\circ} \mathrm{C}$ for 30 min and $80^{\circ} \mathrm{C}$ for $20 \mathrm{~min}$. As shown in Table 3, the viable spore count of a spore suspension enumerated after a heat shock at $90^{\circ} \mathrm{C}$ for $10 \mathrm{~min}$ was found to be $3.17 \pm 0.04 \mathrm{log}$
Table 3. Comparison of viable counts of $C$. sporogenes spores activated under different heat-shock conditions

\begin{tabular}{lccc}
\hline \multirow{2}{*}{ Heat-shock condition } & \multicolumn{2}{c}{$\begin{array}{c}\text { Viable spore count } \\
(\log \mathrm{CFU} / \mathrm{mL})^{1)}\end{array}$} & \multirow{2}{*}{$p$-value } \\
\cline { 2 - 3 } & Mean & Variance & \\
\hline $70^{\circ} \mathrm{C}$ for $30 \mathrm{~min}^{2)}$ & $3.11^{\mathrm{a}}$ & 0.05 & 0.421 \\
$80^{\circ} \mathrm{C}$ for $20 \mathrm{~min}^{2)}$ & $3.17^{\mathrm{a}}$ & 0.05 & \\
$90^{\circ} \mathrm{C}$ for $10 \mathrm{~min}$ & $3.17^{\mathrm{a}}$ & 0.04 & \\
\hline
\end{tabular}

${ }^{1)}$ Values were determined from serially diluted samples to approximately $10^{3} \mathrm{CFU} / \mathrm{mL}$ in sterile $0.1 \%$ peptone water to give a statistically valid range of colonies, and 2 independent experiments were performed in duplicate; Mean values in the same column that are followed by the same letter are not significantly different $(p>0.05$; both Tukey's and Fisher's tests).

${ }^{2}$ Conventional heat-shock condition

$\mathrm{CFU} / \mathrm{mL}$, which showed no statistically significant differences as compared with those enumerated after conventional heat-shock treatments $\left(3.11 \pm 0.05 \log \mathrm{CFU} / \mathrm{mL}, 70^{\circ} \mathrm{C}\right.$ for $30 \mathrm{~min} ; 3.17 \pm 0.05 \log \mathrm{CFU} / \mathrm{mL}, 80^{\circ} \mathrm{C}$ for $20 \mathrm{~min}$ ). Together with the fact that the inactivation rate of the spores was expected to be exceedingly low under the heatshock condition of $90^{\circ} \mathrm{C}$ for $10 \mathrm{~min}$, as described above, these experimental comparative data suggest that this heatshock treatment activates $C$. sporogenes spores, with no significant loss of viability of the spores, when compared with the other conventional heat-shock conditions tested. It is worth noting that the heat shock of $10 \mathrm{~min}$ at $90^{\circ} \mathrm{C}$ evaluated herein activates quickly $C$. sporogenes spores, as compared to the other conventional heat-shock conditions.

The shortest time period of heat activation for $C$. sporogenes spores found in literature was 8 min when the spores were heat-shocked in a boiling water bath (22). However, the heat-shock condition seems to be too severe, considering the inactivation rates $(10-20 \%)$ of spores estimated in this study, which may lead to inaccurate enumeration of inoculum size and survival and thereby to failure of validation of thermal sterilization processes. Due to this, the results obtained in this study strongly suggest that the viability loss of spores should be considered when evaluating the efficiency of heat-shock conditions. Meanwhile, Powell and Hunter (27) reported that as heating temperature increased, the heating time required to deliver the same rate of germination decreased in a non-linear fashion. Similarly, we observed that a $10^{\circ} \mathrm{C}$ decrease in heating temperature leads to the requirement of an increase in heating time of $10 \mathrm{~min}$ in the present study (Table 3). Taken together, it seems likely that the heating temperature of $90^{\circ} \mathrm{C}$ would be the highest we can achieve while activating spores quickly (within $10 \mathrm{~min}$ ) and avoiding the loss of spore viability.

Implication of the study Lack of accuracy of the viable counts of $C$. sporogenes spores may lead to a failure to 
provide reliable data on the heat resistance and thermal inactivation of the spores, which can cause difficulty in both modeling and validating thermal sterilization processes for inactivating $C$. botulinum spores. In the previous studies, we have validated thermal sterilization processes using different food samples inoculated with $C$. sporogenes spores that were activated under a heat-shock condition of $90^{\circ} \mathrm{C}$ for $10 \mathrm{~min}(6,7)$. However, although this heat-shock treatment has been used by industry people and even by our colleagues in the Microwave Sterilization Consortium in the United States, there have been no reports addressing the question of whether a heat shock of $10 \mathrm{~min}$ at $90^{\circ} \mathrm{C}$ is an effective way to activate spores and to kill vegetative cells of $C$. sporogenes and thereby to provide reliable counts of $C$. sporogenes spores with no viability loss, compared with conventional and mild heat-shock conditions. Because of this, we have demonstrated herein that under a heat-shock condition of $90^{\circ} \mathrm{C}$ for $10 \mathrm{~min}$ an accurate and rapid enumeration of the viable counts of $C$. sporogenes spores could be made, providing data on the $\mathrm{D}$ values of both spores and vegetative cells. Thus, we expect that the information provided in this study would be helpful in supporting the accuracy of enumeration data being used for the verification of thermal sterilization processes.

In conclusion, this study indicates that a heat-shock condition of $90^{\circ} \mathrm{C}$ for $10 \mathrm{~min}$ would be appropriate to quickly activate $C$. sporogenes spores and to eliminate the possibilities of the viability loss of spores and survival of vegetative cells, which is likely to be of advantage in enumerating the viable counts of $C$. sporogenes spores. Moreover, with the information on heat tolerance of $C$. sporogenes provided in this study, it is expected to overcome lack of knowledge of the behavior of both spores and vegetative cells of $C$. sporogenes during heat treatments. In addition, the findings from this study would be useful for any studies involving inhibition or inactivation of $C$. sporogenes spores.

Acknowledgments The authors thank Ms. Galina Mikhaylenko for experimental support. This work was partially supported by a Korea University Grant.

\section{References}

1. Ocio MJ, Sánchez T, Fernández PS, Rodrigo M, Martínez A. Thermal resistance characteristics of PA 3679 in the temperature range of $110-121^{\circ} \mathrm{C}$ as affected by $\mathrm{pH}$, type of acidulant, and substrate. Int. J. Food Microbiol. 22: 239-247 (1994)

2. Welt BA, Tong CH, Rossen JL, Lund DB. Effect of microwave radiation on inactivation of Clostridium sporogenes (PA 3679) spores. Appl. Environ. Microb. 60: 482-488 (1994)

3. Guan D, Gray P, Kang D-H, Tang J, Shafer B, Ito K, Younce F, Yang TCS. Microbiological validation of microwave-circulated water combination heating technology by inoculated pack studies. J.
Food Sci. 68: 1428-1432 (2003)

4. McGlynn WG, Davis DR, Johnson MG, Crandall PG. Modified spore inoculation method for thermal-process verification of pinto beans and green beans canned in two large reusable containers. J. Food Sci. 68: 988-991 (2003)

5. IFT (Institute of Food Technologists). Overarching principles: Kinetics and pathogens of concern for all technologies. J. Food Sci. 65(suppl.): 16-31 (2000)

6. Luechapattanaporn K, Wang Y, Wang J, Al-Holy M, Kang D-H, Tang J, Hallberg LM. Microbial safety in radio-frequency processing of packaged foods. J. Food Sci. 69: M201-M206 (2004)

7. Luechapattanaporn K, Wang Y, Wang J, Tang J, Hallberg LM, Dunne CP. Sterilization of scrambled eggs in military polymeric trays by radio frequency energy. J. Food Sci. 70: E288-E294 (2005)

8. Kalchayanand N, Dunne CP, Sikes A, Ray B. Inactivation of bacterial spores by combined action of hydrostatic pressure and bacteriocins in roast beef. J. Food Safety 23: 219-231 (2003)

9. Kalchayanand N, Dunne CP, Sikes A, Ray B. Germination induction and inactivation of Clostridium spores at medium-range hydrostatic pressure treatment. Innov. Food Sci. Emerg. 5: 277-283 (2004)

10. AOAC. Official Methods of Analysis of AOAC Int. $18^{\text {th }}$ ed. Method 966.04. Association of Official Analytical Chemists International, Gaithersburg, MD, USA (2005)

11. Tomasino SF, Hamilton MA. Comparative evaluation of two quantitative test methods for determining the efficacy of liquid sporicides and sterilants on a hard surface: A precollaborative study. J. AOAC Int. 90: 456-464 (2007)

12. Tomasino SF, Samalot-Freire LC. AOAC method 966.04: Preliminary evaluation of cooked meat medium with manganese sulfate for the cultivation of Clostridium sporogenes: Precollaborative study. J. AOAC Int. 90: 825-933 (2007)

13. Keynan A, Evenchick Z. Activation. pp. 359-396. In: The Bacterial Spore. Gould GW, Hurst A (eds). Academic Press, Inc., New York, NY, USA (1969)

14. Turnbull PCB, Frawley DA, Bull RL. Heat activation/shock temperatures for Bacillus anthracis spores and the issue of spore plate counts versus true number of spores. J. Microbiol. Meth. 68: 353-357 (2007)

15. Uehara M, Fujioka RS, Frank HA. Method for obtaining cleaned putrefactive anaerobe 3679 spores. J. Bacteriol. 89: 929-930 (1965)

16. USFDA (US Food and Drug Administration). Clostridium botulinum (Ch. 17). In: Bacteriological Analytical Manual. $8^{\text {th }}$ ed. Rev. A. Available from: http://www.fda.gov/Food/ScienceResearch/ LaboratoryMethods/BacteriologicalAnalyticalManualBAM/ ucm070879.htm. Accessed Apr. 18, 2011.

17. Chung H-J, Wang S, Tang J. Influence of heat transfer with tube methods on measured thermal inactivation parameters for Escherichia coli. J. Food Protect. 70: 851-859 (2007)

18. Bolton DJ, Pearce R, Sheridan JJ, McDowell DA, Blair IS. Decontamination of pork carcasses during scalding and the prevention of Salmonella cross-contamination. J. Appl. Microbiol. 94: 1036-1042 (2003)

19. Byrne B, Dunne G, Bolton DJ. Thermal inactivation of Bacillus cereus and Clostridium perfringens vegetative cells and spores in pork luncheon roll. Food Microbiol. 23: 803-808 (2006)

20. Licciardello JJ, Nickerson JTR. Effect of radiation environment on the thermal resistance of irradiated spores of Clostridium sporogenes P.A. 3679. J. Food Sci. 27: 211-218 (1962)

21. Blank G, Akomas G, Henderson M, Zawistowski J. Heat sensitization of Bacillus subtilis spores by selected spices. J. Food Safety 9: 8396 (1988)

22. Augustin JAL, Pflug IJ. Recovery patterns of spores of putrefactive anaerobe 3679 in various subculture media after heat treatment. Appl. Microbiol. 15: 266-276 (1967)

23. Juneja VK, Marmer BS. Thermal inactivation of Clostridium perfringens vegetative cells in ground beef and turkey as affected by sodium pyrophosphate. Food Microbiol. 15: 281-287 (1998)

24. Juneja VK, Novak JS, Eblen BS, Mcclane BA. Heat resistance of Clostridium perfringens vegetative cells as affected by prior heat 
shock. J. Food Safety 21: 127-139 (2001)

25. Abraham G, Debray E, Candau Y, Piar G. Mathematical model of thermal destruction of Bacillus stearothermophilus spores. Appl. Environ. Microb. 56: 3073-3080 (1990)

26. Mathys A, Heinz V, Schwartz FH, Knorr D. Impact of agglomeration on the quantitative assessment of Bacillus stearothermophilus heat inactivation. J. Food Eng. 81: 380-387 (2007)

27. Powell JF, Hunter JR. Spore germination in the genus Bacillus: The modification of germination requirements as a result of preheating. J. Gen. Microbiol. 13: 59-67 (1955) 